\title{
Front Matter: Volume 11154
}

, "Front Matter: Volume 11154," Proc. SPIE 11154, Active and Passive Microwave Remote Sensing for Environmental Monitoring III, 1115401 (19 November 2019); doi: 10.1117/12.2555607

SPIE. Event: SPIE Remote Sensing, 2019, Strasbourg, France 


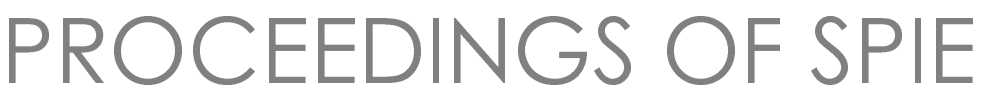

\title{
Active and Passive Microwave Remote Sensing for Environmental Monitoring III
}

\author{
Fabio Bovenga \\ Claudia Notarnicola \\ Nazzareno Pierdicca \\ Emanuele Santi \\ Editors
}

11-12 September 2019

Strasbourg, France

Sponsored by

SPIE

Cooperating Organisations

European Optical Society

ISPRS - International Society for Photogrammetry and Remote Sensing

EARSeL-European Association of Remote Sensing Laboratories (Germany)

Published by

SPIE 
The papers in this volume were part of the technical conference cited on the cover and title page. Papers were selected and subject to review by the editors and conference program committee. Some conference presentations may not be available for publication. Additional papers and presentation recordings may be available online in the SPIE Digital Library at SPIEDigitallibrary.org.

The papers reflect the work and thoughts of the authors and are published herein as submitted. The publisher is not responsible for the validity of the information or for any outcomes resulting from reliance thereon.

Please use the following format to cite material from these proceedings:

Author(s), "Title of Paper," in Active and Passive Microwave Remote Sensing for Environmental Monitoring III, edited by Fabio Bovenga, Claudia Notarnicola, Nazzareno Pierdicca, Emanuele Santi, Proceedings of SPIE Vol. 11154 (SPIE, Bellingham, WA, 2019) Seven-digit Article CID Number.

ISSN: 0277-786X

ISSN: 1996-756X (electronic)

ISBN: 9781510630116

ISBN: 9781510630123 (electronic)

Published by

SPIE

P.O. Box 10, Bellingham, Washington 98227-0010 USA

Telephone +13606763290 (Pacific Time) · Fax +1 3606471445

SPIE.org

Copyright @ 2019, Society of Photo-Optical Instrumentation Engineers.

Copying of material in this book for internal or personal use, or for the internal or personal use of specific clients, beyond the fair use provisions granted by the U.S. Copyright Law is authorized by SPIE subject to payment of copying fees. The Transactional Reporting Service base fee for this volume is $\$ 21.00$ per article (or portion thereof), which should be paid directly to the Copyright Clearance Center (CCC), 222 Rosewood Drive, Danvers, MA 01923. Payment may also be made electronically through CCC Online at copyright.com. Other copying for republication, resale, advertising or promotion, or any form of systematic or multiple reproduction of any material in this book is prohibited except with permission in writing from the publisher. The CCC fee code is 0277$786 \times / 19 / \$ 21.00$.

Printed in the United States of America by Curran Associates, Inc., under license from SPIE.

Publication of record for individual papers is online in the SPIE Digital Library.

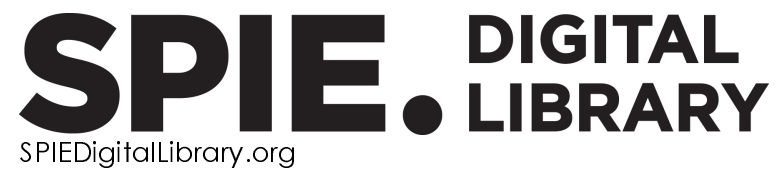

Paper Numbering: Proceedings of SPIE follow an e-First publication model. A unique citation identifier (CID) number is assigned to each article at the time of publication. Utilization of CIDs allows articles to be fully citable as soon as they are published online, and connects the same identifier to all online and print versions of the publication. SPIE uses a seven-digit CID article numbering system structured as follows:

- The first five digits correspond to the SPIE volume number.

- The last two digits indicate publication order within the volume using a Base 36 numbering system employing both numerals and letters. These two-number sets start with $00,01,02,03,04$, 05, 06, 07, 08, 09, OA, OB ... 0Z, followed by 10-1Z, 20-2Z, etc. The CID Number appears on each page of the manuscript. 


\title{
Contents
}

\author{
$\checkmark \quad$ Authors \\ vii Conference Committee
}

SAR DATA PROCESSING II: JOINT SESSION

1115405 Capsule and convolutional neural network-based SAR ship classification in Sentinel-1 data [1 $11154-4]$

SOIL MOISTURE AND BIOMASS MONITORING II

11154 OD Evaluation of backscatter coefficient temporal indices for burned area mapping (Best Student Paper Award) [1 $1154-12]$

\section{POSTER SESSION}

$11154 \mathrm{OH} \quad$ Landslide detection with ALOS-2/PALSAR-2 data using convolutional neural networks: a case study of 2018 Hokkaido Eastern Iburi earthquake [1 $1154-6$ ]

11154 OJ Investigation of ground deformation with PSInSAR approach in an unstable urban area Naples, Italy using X-band SAR images [1 $11154-17$ ]

11154 OM SWE retrieval by exploiting COSMO-SkyMed X-band SAR imagery and ground data through a machine learning approach [1 $11154-22]$ 
Proc. of SPIE Vol. 11154 1115401-4

Downloaded From: https://www.spiedigitallibrary.org/conference-proceedings-of-spie on 26 Apr 2023 Terms of Use: https://www.spiedigitallibrary.org/terms-of-use 


\section{Authors}

Numbers in the index correspond to the last two digits of the seven-digit citation identifier (CID) article numbering system used in Proceedings of SPIE. The first five digits reflect the volume number. Base 36 numbering is employed for the last two digits and indicates the order of articles within the volume. Numbers start with 00, 01, 02, 03, 04, 05, 06, 07, 08, 09, OA, OB...0Z, followed by 10-12, 20-2Z, etc.

Belenguer-Plomer, Miguel A., OD

Biswas, Kousik, OJ

Bruzzone, Lorenzo, OM

Chakravarty, Debashish, 0J

Chuvieco, Emilio, OD

Cigna, Francesca, OM

Cuozzo, Giovanni, OM

De Gregorio, Ludovica, OM

De Laurentiis, Leonardo, 05

Del Frate, Fabio, 05

Jacob, Alexander, $0 \mathrm{M}$

Konishi, Tomohisa, $\mathrm{OH}$

Misra, Arundhati, OJ

Mitra, Pabitra, OJ

Notarnicola, Claudia, OM

Paloscia, Simonetta, OM

Pettinato, Simone, OM

Pomente, Andrea, 05

Santi, Emanuele, $\mathrm{OM}$

Schiavon, Giovanni, 05

Suga, Yuzo, $\mathrm{OH}$

Tanase, Mihai A., OD

Tapete, Deodato, OM 
Proc. of SPIE Vol. $111541115401-6$

Downloaded From: https://www.spiedigitallibrary.org/conference-proceedings-of-spie on 26 Apr 2023 Terms of Use: https://www.spiedigitallibrary.org/terms-of-use 


\title{
Conference Committee
}

\author{
Symposium Chairs
}

Christopher M. U. Neale, University of Nebraska Lincoln (United States) and Daugherty Water for Food Institute (United States)

Karsten Schulz, Fraunhofer-Institut für Optronik, Systemtechnik und Bildauswertung (Germany)

Conference Chairs

Fabio Bovenga, CNR Istituto per il Rilevamento Elettromagnetico dell'Ambiente (Italy)

Claudia Notarnicola, EURAC (Italy)

Nazzareno Pierdicca, Sapienza Università di Roma (Italy)

Emanuele Santi, Istituto di Fisica Applicata "Nello Carrara" (Italy)

Conference Programme Committee

Maria-Paola Clarizia, University of Michigan (United States)

Fabio Covello, Agenzia Spaziale Italiana (Italy)

Katarzyna Dabrowska-Zielinska, Institute of Geodesy and

Cartography (Poland)

Mihai P. Datcu, Deutsches Zentrum für Luft- und Raumfahrt e.V. (Germany)

Fabio Del Frate, Università degli Studi di Roma "Tor Vergata" (Italy)

Dara Entekhabi, Massachusetts Institute of Technology (United States)

Carlos Lopez-Martinez, Universidad Politècnica de Catalunya (Spain)

Simonetta Paloscia, Istituto di Fisica Applicata "Nello Carrara" (Italy)

Luca Pulvirenti, CIMA Research Foundation (Italy)

Stefan Schneiderbauer, EURAC (Italy)

David Small, Universität Zürich (Switzerland)

Session Chairs

1 SAR Data Processing I: Joint Session

Lorenzo Bruzzone, Università degli Studi di Trento (Italy)

2 SAR Data Processing II: Joint Session

Claudia Notarnicola, EURAC (Italy)

3 Soil Moisture and Biomass Monitoring I

Nazzareno Pierdicca, Sapienza Università di Roma (Italy)

4 Soil Moisture and Biomass Monitoring II

Emanuele Santi, Istituto di Fisica Applicata "Nello Carrara" (Italy) 
Proc. of SPIE Vol. 11154 1115401-8

Downloaded From: https://www.spiedigitallibrary.org/conference-proceedings-of-spie on 26 Apr 2023 Terms of Use: https://www.spiedigitallibrary.org/terms-of-use 